\title{
Article \\ Enhancement of Glucosinolate Formation in Broccoli Sprouts by Hydrogen Peroxide Treatment
}

\author{
Adriana Vanegas Torres ${ }^{1,2}\left(\mathbb{D}\right.$, Nimrod Tish $^{1,3}$ and Victor $\operatorname{Rodov}^{1, *(D)}$ \\ 1 Department of Postharvest Science, Agricultural Research Organization (ARO)—The Volcani Institute, \\ Rishon LeZion 7505101, Israel; adriana.vanegas@mail.huji.ac.il (A.V.T.); nimrod.tish@mail.huji.ac.il (N.T.) \\ 2 The Robert H. Smith Faculty of Agriculture, Food and Environment, The Hebrew University of Jerusalem, \\ Rehovot 7610001, Israel \\ 3 The Goodman Faculty of Life Sciences, Bar-Ilan University, Ramat Gan 5290002, Israel \\ * Correspondence: vrodov@agri.gov.il
}

check for updates

Citation: Vanegas Torres, A.; Tish, N.; Rodov, V. Enhancement of Glucosinolate Formation in Broccoli Sprouts by Hydrogen Peroxide Treatment. Foods 2022, 11, 655. https://doi.org/10.3390/ foods11050655

Academic Editor: Dunja Šamec

Received: 20 January 2022

Accepted: 17 February 2022

Published: 23 February 2022

Publisher's Note: MDPI stays neutral with regard to jurisdictional claims in published maps and institutional affiliations.

Copyright: (C) 2022 by the authors. Licensee MDPI, Basel, Switzerland. This article is an open access article distributed under the terms and conditions of the Creative Commons Attribution (CC BY) license (https:// creativecommons.org/licenses/by/ $4.0 /)$

\begin{abstract}
Broccoli sprouts are known as a rich source of health-beneficial phytonutrients: glucosinolates and phenolic compounds. The production of phytonutrients can be stimulated by elicitors that activate the plant stress response. The aim of this study was enhancing the nutritional value of broccoli sprouts using hydrogen peroxide $\left(\mathrm{H}_{2} \mathrm{O}_{2}\right)$ as an elicitor. Daily spraying with $\mathrm{H}_{2} \mathrm{O}_{2}(500-1000 \mathrm{mM})$ enhanced the accumulation of glucosinolates, doubling their content in the cotyledons of $16 / 8 \mathrm{~h}$ photoperiod-grown 7-day sprouts compared to the water-treated controls. The application of $\mathrm{H}_{2} \mathrm{O}_{2}$ on dark-grown sprouts showed a smaller extent of glucosinolate stimulation than with light exposure. The treatment affected sprout morphology without reducing their yield. The $\mathrm{H}_{2} \mathrm{O}_{2}$-treated sprouts had shorter hypocotyls and roots, negative root tropism and enhanced root branching. The activated glucosinolate production became evident $24 \mathrm{~h}$ after the first $\mathrm{H}_{2} \mathrm{O}_{2}$ application and continued steadily until harvest. Applying the same treatment to greenhouse-grown wild rocket plants caused scattered leaf bleaching, a certain increase in glucosinolates but decline in phenolics content. The $\mathrm{H}_{2} \mathrm{O}_{2}$ treatment of broccoli sprouts caused a 3.5-fold upregulation of APK1, a gene related to sulfur mobilization for glucosinolate synthesis. Comparing the APK1 expression with the competing gene GSH1 using sulfur for antioxidant glutathione production indicated that glutathione synthesis prevailed in the sprouts over the formation of glucosinolates.
\end{abstract}

Keywords: Brassica oleracea var. italica; sprouts; elicitation; phytonutrients; glucosinolates; phenolic compounds; wild rocket; Diplotaxis tenuifolia; gene expression; sulfur metabolism

\section{Introduction}

Plants from the Brassicaceae family such as broccoli, cabbage, Brussels sprouts, kale, mustard, radish, etc., are valuable sources of health-beneficial natural compounds for human nutrition (phytonutrients), helpful for preventing chronic diseases [1-4]. The Brassicaceae phytonutrients include, in particular, phenolic compounds known as potent antioxidants [5] and glucosinolates, a group of nitrogen- and sulfur-containing anti-cancer secondary metabolites [6]. Glucosinolates are found in plant vacuoles and comprise a $\beta$-D-thioglucose group, a sulfonated oxime group and a side chain derived from an amino acid [7]. Depending on the amino acid in the side chain, the glucosinolates can be classified into aliphatic (based on methionine), indolic (based on tryptophan) and aromatic (based on tyrosine or phenylalanine) glucosinolates [8].

Glucosinolates contribute to the health benefit of the Brassicaceae crops through their hydrolysis by an enzyme myrosinase that generates bioactive volatile pungent compounds isothiocyanates along with other products, e.g., nitriles $[9,10]$. The hydrolysis is activated upon tissue disruption by chewing, cutting, attack of phytopathogens, herbivores or gastrointestinal microbiota [11-13]. One prominent glucosinolate is glucoraphanin, a precursor of an isothiocyanate sulforaphane possessing potent anti-cancer activity [14]. 
Young sprouts of broccoli were found to be an exceptionally rich source of glucosinolates and isothiocyanates containing 10-100 times higher levels of glucoraphanin than the mature plants [15]. Broccoli sprouts were shown to possess high antioxidant, anti-proliferative and antibacterial properties [16]. In general, edible sprouts are known as functional foods rich in phytonutrients $[17,18]$.

A number of genes are involved in glucosinolate formation [19], in particular MYB transcription factors regulating the biosynthesis of aliphatic and indole glucosinolates [20-22]. Other relevant genes are from the Cytochrome P450s family (CYPs) involved in the core glucosinolate biosynthesis, e.g., CYP79F1 for aliphatic path and CYP79B3 for indole path [20]. Duarte-Sierra et al. [23] showed the upregulation of CYP79 family genes after oxidative stresses in broccoli florets. Guo et al. [24] revealed that heat and hypoxia stresses in broccoli sprouts resulted in the enhanced accumulation of aliphatic glucosinolates and expression of relevant genes including CYP83A1. APS kinases (APKs) are another group of redoxregulated genes mobilizing sulfur for glucosinolate synthesis [25]. Alternatively, sulfur may be used for the production of antioxidant glutathione (GSH) involved in the detoxification of reactive oxygen species [26].

The biological role of sulfur-containing and phenolic phytonutrients in Brassicaceae plants is associated with defense against biotic (pathogens, pests, herbivores) and abiotic (cold, heat, irradiation) stresses [12]. Therefore, the content of phytonutrients can be enhanced by treatment with elicitors, i.e., factors that induce plant defense responses through various signaling pathways $[27,28]$. In particular, the defense responses can be elicited by interventions associated with oxidative stress, e.g., hydrogen peroxide $\left(\mathrm{H}_{2} \mathrm{O}_{2}\right)$ or ultraviolet light $[29,30]$. Reactive oxygen species (ROS) such as $\mathrm{H}_{2} \mathrm{O}_{2}$ are naturally produced by cells in course of reduction/oxidation (redox) reactions, and their levels are controlled by antioxidant enzymes [31]. $\mathrm{H}_{2} \mathrm{O}_{2}$ is involved in many physiological processes such as seed germination, acting both as a plant development regulator and a direct antimicrobial protection agent [32,33]. At the same time, $\mathrm{H}_{2} \mathrm{O}_{2}$ acts as a signaling molecule inducing the plant's defense response towards biotic and abiotic stresses [34]. Depending on the concentration used, exogenous $\mathrm{H}_{2} \mathrm{O}_{2}$ can induce a signaling cascade leading to defense molecules (e.g., phytoalexins) production or cause phytotoxic damage [35]. It was shown that the application of $\mathrm{H}_{2} \mathrm{O}_{2}$ increased the content of polyphenols in lentil and mungbean sprouts [29,30]. However, no data are available about the effect of $\mathrm{H}_{2} \mathrm{O}_{2}$ on glucosinolates content in Brassicaceae sprouts. The only somewhat relevant information is the conference report of Arriaga-Madrid et al. [36] about the increased accumulation of glucosinolates in some organs (primarily flowers and seeds) of adult mustard plants sprayed with $\mathrm{H}_{2} \mathrm{O}_{2}$ throughout the greenhouse crop cycle.

In this work, we investigated the possibility of improving the nutritional value of broccoli sprouts by the application of hydrogen peroxide as elicitor enhancing the production of phytonutrients-glucosinolates and phenolic compounds. In addition, the performance of elicitor treatment that showed the highest efficacy with broccoli sprouts was examined with greenhouse-grown wild rocket plants.

\section{Materials and Methods}

\subsection{Materials}

Organic broccoli seeds (Brassica oleracea $\mathrm{cv}$. Calabrese) were purchased from Eco-Store, Tel Aviv-Yafo, Israel. Hydrogen peroxide, palladium (II) chloride $\left(\mathrm{PdCl}_{2}\right)$, Folin-Ciocalteu's phenol reagent, sinigrin and gallic acid standards and Spectrum ${ }^{\mathrm{TM}}$ Plant Total RNA Kit were purchased from Sigma Israel, Rehovot, Israel. Maxima first strand cDNA synthesis Kit with dsDNAase and Fast SYBR green Master mix were purchased from Thermo Fisher Scientific.

\subsection{Plant Material and Sprouting Procedure}

Broccoli seeds were sterilized in $2 \%$ of calcium hypochlorite as recommended by FDA [37], rinsed 7-8 times with distilled water and soaked for $4 \mathrm{~h}$. The seeds were germinated and further grown in custom-made two-layer containers comprising inner 
perforated and outer non-perforated plastic cups (Figure 1), approximately 300 seeds per container. The seeds were spread on the bottom of the perforated cup inserted in the non-perforated one that contained ca. $1 \mathrm{~mL}$ water to maintain a moist environment without covering the seeds.

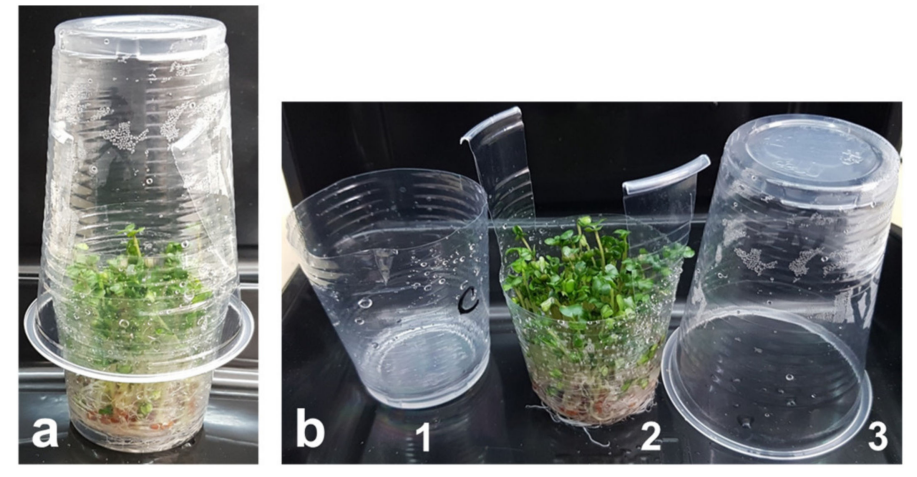

Figure 1. Sprouting container: assembled (a) and disassembled (b) into three parts: 1 -non-perforated outer drainage cup; 2-perforated inner growing cup; and 3-transparent cover. During the first three days of sprouting, a light-impermeable cup completely covering the container was used instead of the transparent cover.

The sprouting containers were kept for 7 days at $22{ }^{\circ} \mathrm{C}$ in an illuminated chamber with $16 / 8 \mathrm{~h}$ light-dark cycle with a photosynthetically activity radiation (PAR) level of $150 \mu \mathrm{mol} \mathrm{m} \mathrm{m}^{-2} \mathrm{~s}^{-1}$. During the first three days, the containers were covered with lightimpermeable paperboard cups to avoid light exposure. Starting from the morning of day 3, the paperboard covers were changed for transparent plastic cups to allow light exposure of the sprouts. Once a day, the sprouts were rinsed with distilled water and sprayed (ca. $1.5 \mathrm{~mL}$ per container) with water or $\mathrm{H}_{2} \mathrm{O}_{2}$. In the control, the sprouts were sprayed with distilled water throughout the growing cycle. In the treatments, the germinating seeds were sprayed with water on the first day and from day 2 until day 6 with $\mathrm{H}_{2} \mathrm{O}_{2}(20$ to $1000 \mathrm{mM}$ in different treatments). The $\mathrm{H}_{2} \mathrm{O}_{2}$ solutions were freshly prepared from recently purchased commercial $30 \%$ hydrogen peroxide whose concentration was verified spectrophotometrically at a wavelength of $240 \mathrm{~nm}$ and extinction coefficient of $43.6 \mathrm{M}^{-1} \mathrm{~cm}^{-1}$ [38].

Modified procedures of sprout growing and treatment were tested in some trials. One modification included a single $\mathrm{H}_{2} \mathrm{O}_{2}$ application on day 2 followed by water sprays until day 6. In another case, the sprouts were repeatedly sprayed with $\mathrm{H}_{2} \mathrm{O}_{2}$ as described above, but they were consistently kept under light-impermeable covers until day 7 without light exposure, except for brief spraying sessions once a day. Irrespectively of the growing procedure peculiarities, the seven-day-old sprouts were harvested, weighed and lyophilized to obtain the dry material. The lyophilized material was weighed again, ground in a mortar to obtain a dry powder that was put in Eppendorf tubes and quickly frozen in liquid nitrogen. If the powder was not used the same day, it was stored at $-80{ }^{\circ} \mathrm{C}$ to avoid myrosinase activity.

In the trials with wild rocket (Diplotaxis tenuifolia) plants, the rocket seeds were sown in a planting mix. During the first 2 days, they were kept in the dark at $23^{\circ} \mathrm{C}$. Then, the seedlings were exposed to nature light conditions for about $14 \mathrm{~h}$. The plants were watered every day. At 12 days of age, the seedlings were transplanted to pots containing the planting mix. The pots belonging to the control and treatment groups were kept in separate bins. Seven days after the transplantation, when the rosette leaves were well-developed, the treatment with $1000 \mathrm{mM}$ of $\mathrm{H}_{2} \mathrm{O}_{2}$ started. The control group was sprayed with distilled water. The $\mathrm{H}_{2} \mathrm{O}_{2}$ or water sprays were applied daily for 4 days, and the following day after the last treatment, the leaves were harvested, weighed, promptly frozen in liquid nitrogen and lyophilized. The dried material was weighed, put in microfuge tubes with addition of grinder beads and crushed using a Geno/Grinder 2666. The dry powder was stored at $-80{ }^{\circ} \mathrm{C}$ until the analysis. 


\subsection{Extraction of Phytochemicals}

The procedure of Villarreal-García et al. [39] was followed for extracting the glucosinolates and phenolic compounds from the dry powder. Aqueous 70\% methanol (10 mL) heated to $70{ }^{\circ} \mathrm{C}$ was added to $0.2 \mathrm{~g}$ of the freeze-dried powder. Taking care of the myrosinase deactivation, the samples were incubated for $30 \mathrm{~min}$ at $70{ }^{\circ} \mathrm{C}$ with vortexing every $10 \mathrm{~min}$. After cooling down to room temperature, the samples were centrifuged $(13,000 \times g$, $10 \mathrm{~min}, 4^{\circ} \mathrm{C}$ ), and the supernatant collected for the analysis of glucosinolates and phenolic compounds [40].

\subsection{Total Glucosinolates Analysis}

Total glucosinolates (GSL) content was determined via palladium colorimetric analysis. Following Ishida et al.'s [41] procedure, the samples were prepared by mixing $0.2 \mathrm{~mL}$ of the crude extract with $0.3 \mathrm{~mL}$ of distilled water and $3 \mathrm{~mL}$ of $2 \mathrm{mM} \mathrm{PdCl}_{2}$ (35.5 mg PdCl $2+168 \mu \mathrm{L}$ of hydrochloric acid $+100 \mathrm{~mL}$ of distilled water). After the reagent addition and mixing, the samples were incubated at room temperature for $1 \mathrm{~h}$, and absorbance at $425 \mathrm{~nm}$ was measured with a spectrophotometer Genesys 10S UV-VIS (Thermo Scientific, Waltham, MA, USA). A blank sample comprised distilled water and $\mathrm{PdCl}_{2}$ solution. The calculation of total GSL content $\left(\mu \mathrm{mol} \mathrm{g}{ }^{-1}\right)$ was based on the absorbance difference between the sample and the blank using the calibration curve prepared with sinigrin as a standard glucosinolate.

\subsection{Total Phenolic Compounds Analysis}

Phenolic compounds were analyzed by the Folin-Ciocalteu method [42]. The samples were prepared by mixing $0.1 \mathrm{~mL}$ of the crude extract with $6 \mathrm{~mL}$ of distilled water and $0.5 \mathrm{~mL}$ of FC reagent. After incubation for $3 \mathrm{~min}, 1.5 \mathrm{~mL}$ of sodium carbonate $\mathrm{Na}_{2} \mathrm{CO}_{3}$ solution (20\%) was added, mixed again and filled with water to obtain $10 \mathrm{~mL}$ of volume. The samples were incubated at room temperature for $2 \mathrm{~h}$, and absorbance at $765 \mathrm{~nm}$ was measured with a spectrophotometer Genesys 10S UV-VIS. A blank sample was prepared with the same procedure without the addition of the crude extract. The calculation of total phenolic compounds content $\left(\mathrm{mg} \mathrm{g}^{-1}\right)$ was based on absorbance difference between the sample and the blank using the calibration curve prepared with gallic acid as a standard phenolic following the procedure of Slinkard \& Singleton [43]. Total phenolic content was expressed as mg gallic acid equivalents (GAE) per g sprouts mass (dry or fresh).

\subsection{RNA Extraction and Real Time-PCR (RT-qPCR) Analysis}

RNA was extracted from sprouts after a single treatment with $1000 \mathrm{mM} \mathrm{H} \mathrm{H}_{2}$ or water (control) applied at day 2 with subsequent incubation of $15 \mathrm{~h}$ in the dark at $22{ }^{\circ} \mathrm{C}$. The sprouts were harvested and immediately frozen in liquid nitrogen to avoid RNA degradation. Then, samples were lyophilized and ground using a mortar and pestle. The crushing was performed using liquid nitrogen, preventing the samples from thawing out. The sprout powder was stored at $-80^{\circ} \mathrm{C}$. RNA extraction was performed with $10 \mathrm{mg}$ of powder and following the protocol of Spectrum ${ }^{\mathrm{TM}}$ Plant Total RNA Kit. The RNA yield was verified by NanoDrop ND-1000 spectrophotometer (NanoDrop Technologies, Wilmington, DE, USA), and electrophoresis was run in order to verify the quality of the RNA. cDNA was synthesized using Maxima first strand cDNA synthesis Kit with dsDNAase. For amplification of the cDNA, primers were designed using Integrated DNA Technologies (IDT) and Primer3Plus software according to the gene sequence of Brassica oleracea var. italica, Brassica oleracea var. oleraceae and Arabidopsis thaliana. Additionlly, primers already evaluated were selected, such as the housekeeping gene $\beta$-actin [24] and MYB29 [22]. In order to run the RT-PCR, $10 \mu \mathrm{L}$ of mixture was prepared for each well on a MicroAmp Fast Optical 96-Well Reaction Plate, including $5 \mu \mathrm{L}$ of Fast SYBR Green Master mix, $2.2 \mu \mathrm{L}$ RNAse-free water, $0.3 \mu \mathrm{L}$ primer mix (forward and reverse primers) and $2.5 \mu \mathrm{L}$ of diluted cDNA. RT-PCR was run on StepOne Plus Real-Time PCR system and analyzing using StepOne software v. 2.2.2. 


\subsection{Statistical Analysis}

The trials and assays were carried out in triplicates. Trials were repeated at least twice with similar outcomes, and the results of typical trials are presented. The data were evaluated by analyzing variance (ANOVA) using JMP Pro 2015 software (SAS Institute, Cary, NC, USA). In addition, a Tukey's HSD test was used for a post hoc pairwise comparison. In some analyses, such as RT-qPCR, Student's $t$-test was run. Data were expressed as means \pm standard error, and $p$ value of $<0.05$ was considered significant.

\section{Results}

\subsection{Effects of Hydrogen Peroxide $\left(\mathrm{H}_{2} \mathrm{O}_{2}\right)$ on Broccoli Sprouts}

Hydrogen peroxide was initially tested in four concentrations (20, 50, 100, $200 \mathrm{mM})$. None of these $\mathrm{H}_{2} \mathrm{O}_{2}$ concentrations showed a statistically significant effect on the sprouts' yields. The total contents of glucosinolates and of phenolic compounds tended to decrease when the sprouts were exposed to the lowest $\mathrm{H}_{2} \mathrm{O}_{2}$ dose $(20 \mathrm{mM})$ and to return to the control level with higher concentrations. Furthermore, at 100 and $200 \mathrm{mM} \mathrm{H}_{2} \mathrm{O}_{2}$, the glucosinolate content values were ca. $20 \%$ higher than in the control, although the difference was not statistically significant (data not shown).

Taking into account that the first $\mathrm{H}_{2} \mathrm{O}_{2}$ application showed a certain increase in glucosinolates with the highest $\mathrm{H}_{2} \mathrm{O}_{2}$ concentration used $(200 \mathrm{mM})$, even higher $\mathrm{H}_{2} \mathrm{O}_{2}$ doses were tested in the new trial, bringing a significant enhancement of the glucosinolate accumulation. $\mathrm{H}_{2} \mathrm{O}_{2}$ at 500 and $1000 \mathrm{mM}$ increased the glucosinolate content by $64 \%$ and $104 \%$, respectively, on a fresh weight basis, or $45 \%$ and $63 \%$, respectively on a dry weight basis (Figure 2c,d). With $200 \mathrm{mM} \mathrm{H}_{2} \mathrm{O}_{2}$, the increase was not statistically significant, similar to the results of the previous trial. The phenolics content calculated on a fresh weight basis did not significantly differ at any concentration of $\mathrm{H}_{2} \mathrm{O}_{2}$. However, on the dry weight basis, the highest $\mathrm{H}_{2} \mathrm{O}_{2}$ concentration $(1000 \mathrm{mM})$ caused a small but significant reduction of $17 \%$ in the phenolics content as compared to the control (Figure 2e,f).
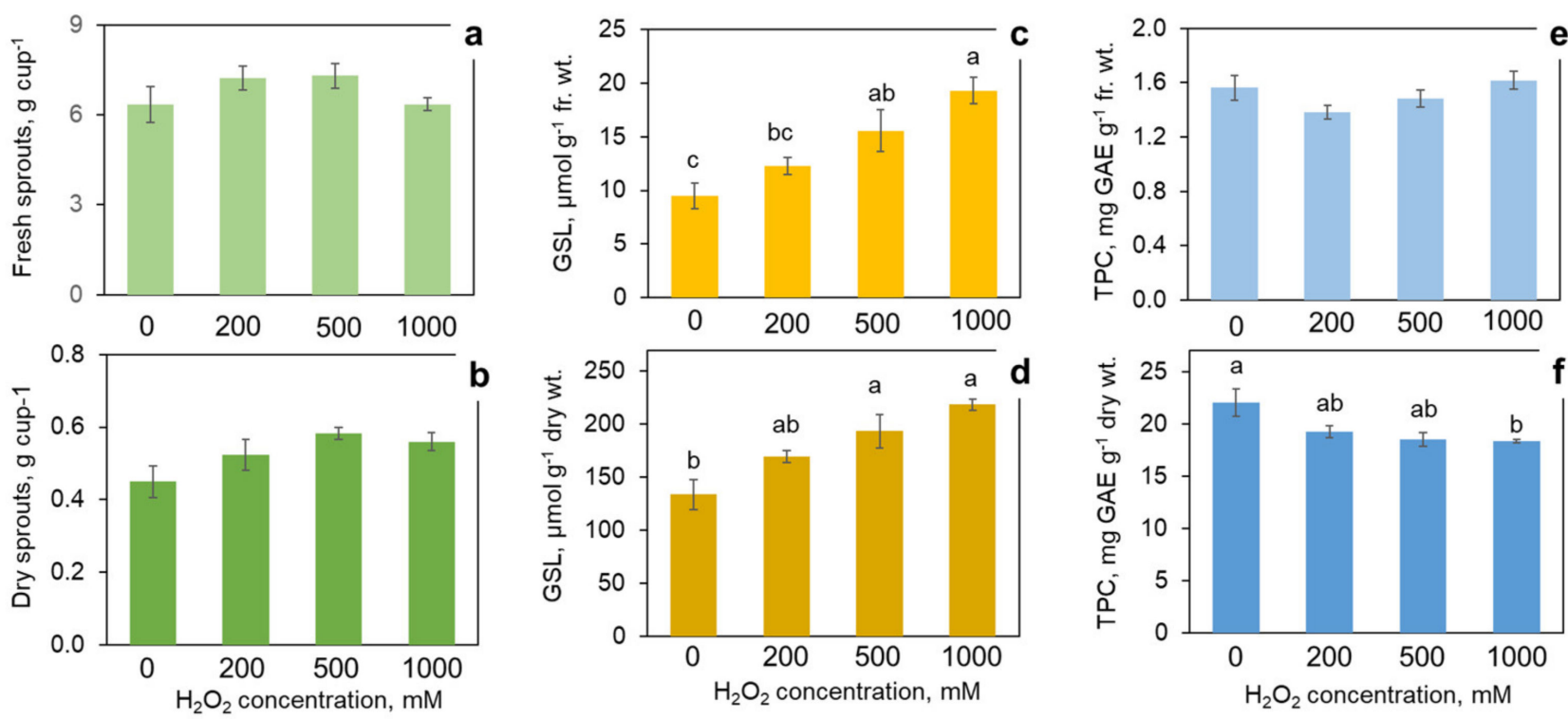

Figure 2. Effect of hydrogen peroxide $\mathrm{H}_{2} \mathrm{O}_{2}$ treatment in concentrations of 0 (control), 200, 500 and $1000 \mathrm{mM}$ on the yield of fresh (a) and dry (b) 7-day broccoli sprouts and on the content of phytonutrients: glucosinolates (GSL) on fresh (c) and dry (d) weight basis, and total phenolic compounds (TPC) on fresh (e) and dry (f) weight basis. Error bars represent standard errors of three independent biological replications. Bars marked by different letters indicate significantly different values according to post-hoc Tukey's HSD test $(p \leq 0.05)$. Absence of letters means that the values were not significantly different according to ANOVA test. 
The high concentrations of $\mathrm{H}_{2} \mathrm{O}_{2}$ caused morphological changes in the broccoli sprouts most evident with $1000 \mathrm{mM} \mathrm{H}_{2} \mathrm{O}_{2}$ (Figure 3). The sprouts treated with $1000 \mathrm{mM}$ of $\mathrm{H}_{2} \mathrm{O}_{2}$ were noticeably shorter than the control. The treatment resulted in a marked inhibition of root growth. Remarkably, the roots demonstrated negative tropism when some of them grew upwards, as if they were trying to escape the high concentration of $\mathrm{H}_{2} \mathrm{O}_{2}$ accumulated on the bottom of the cup after spraying. In contrast with the inhibited primary root elongation, there was a prominent stimulation of lateral root development (Figure 4). In spite of the obvious effect of the high $\mathrm{H}_{2} \mathrm{O}_{2}$ concentrations on the sprout morphology, they did not cause a significant change in the fresh and dry weight yield (Figure 2a,b). It can be inferred that the treatment resulted in thicker and/or denser sprouts (Figure 4).

a

b
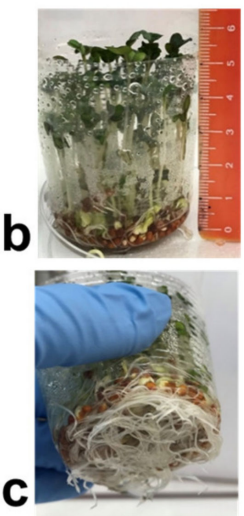

\section{$\mathrm{H}_{2} \mathrm{O}_{2}$ concentration, $\mathrm{mM}$}
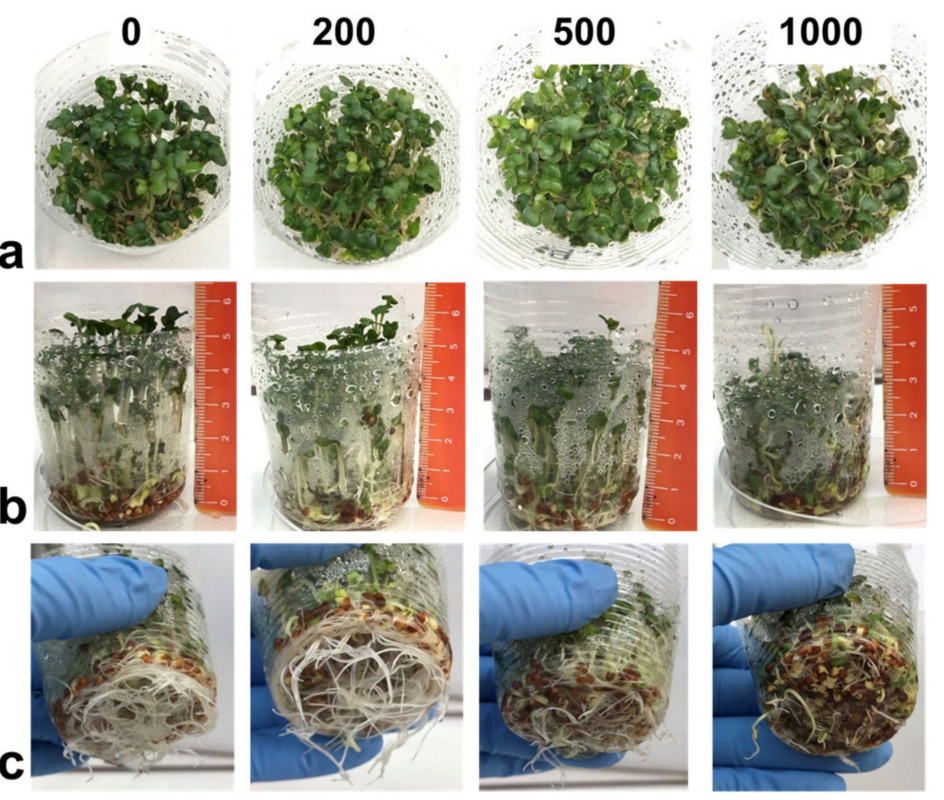

Figure 3. Effect of hydrogen peroxide $\mathrm{H}_{2} \mathrm{O}_{2}$ treatment in concentrations of 0 (control), 200, 500 and $1000 \mathrm{mM}$ on the appearance of 7-day broccoli sprouts: view from the top (a), side (b) and bottom (c). Note the negative root tropism in the $1000 \mathrm{mM} \mathrm{H}_{2} \mathrm{O}_{2}$ treatment.

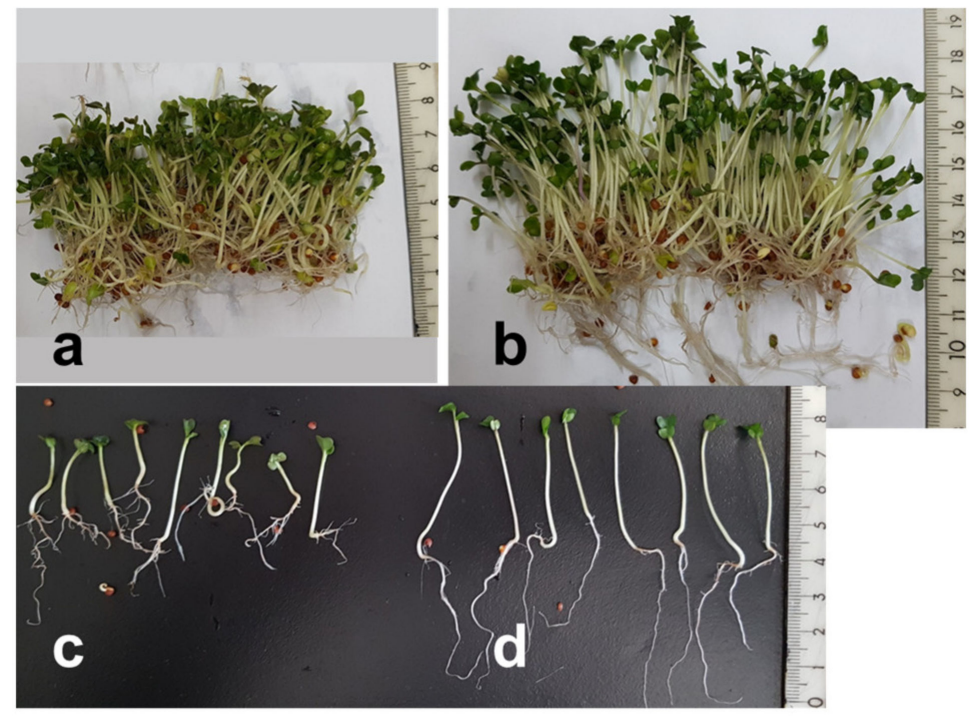

Figure 4. Effect of hydrogen peroxide treatment on the appearance of 7-day broccoli sprouts. Content of one growing container: treated with $1000 \mathrm{mM} \mathrm{H}_{2} \mathrm{O}_{2}$ (a) and control (b); individual sprouts: treated with $1000 \mathrm{mM} \mathrm{H}_{2} \mathrm{O}_{2}$ (c) and control (d). 


\subsection{Factors Affecting the Glucosinolate Accumulation in $\mathrm{H}_{2} \mathrm{O}_{2}$-Treated Sprouts}

A separate trial investigated the time course of sprout development and glucosinolate accumulation in $\mathrm{H}_{2} \mathrm{O}_{2}$-treated vs. control samples during the 7-day growth cycle. The appearance evolution of the plant material during the growth cycle is presented in Figure 5. One characteristic morphological feature of the control sprouts was the development of fluffy root hairs on day 3 that gave more surface to absorb water. However, the root hairs were much less visible in the $\mathrm{H}_{2} \mathrm{O}_{2}$-treated sprouts (Figure 5). Another morphological peculiarity of the $\mathrm{H}_{2} \mathrm{O}_{2}$-treated sprouts, the negative root tropism, became evident on day 4. Figures 3-5 show that spraying with $1000 \mathrm{mM} \mathrm{H}_{2} \mathrm{O}_{2}$ caused no visible phytotoxic effects (e.g., bleaching) on broccoli cotyledons.

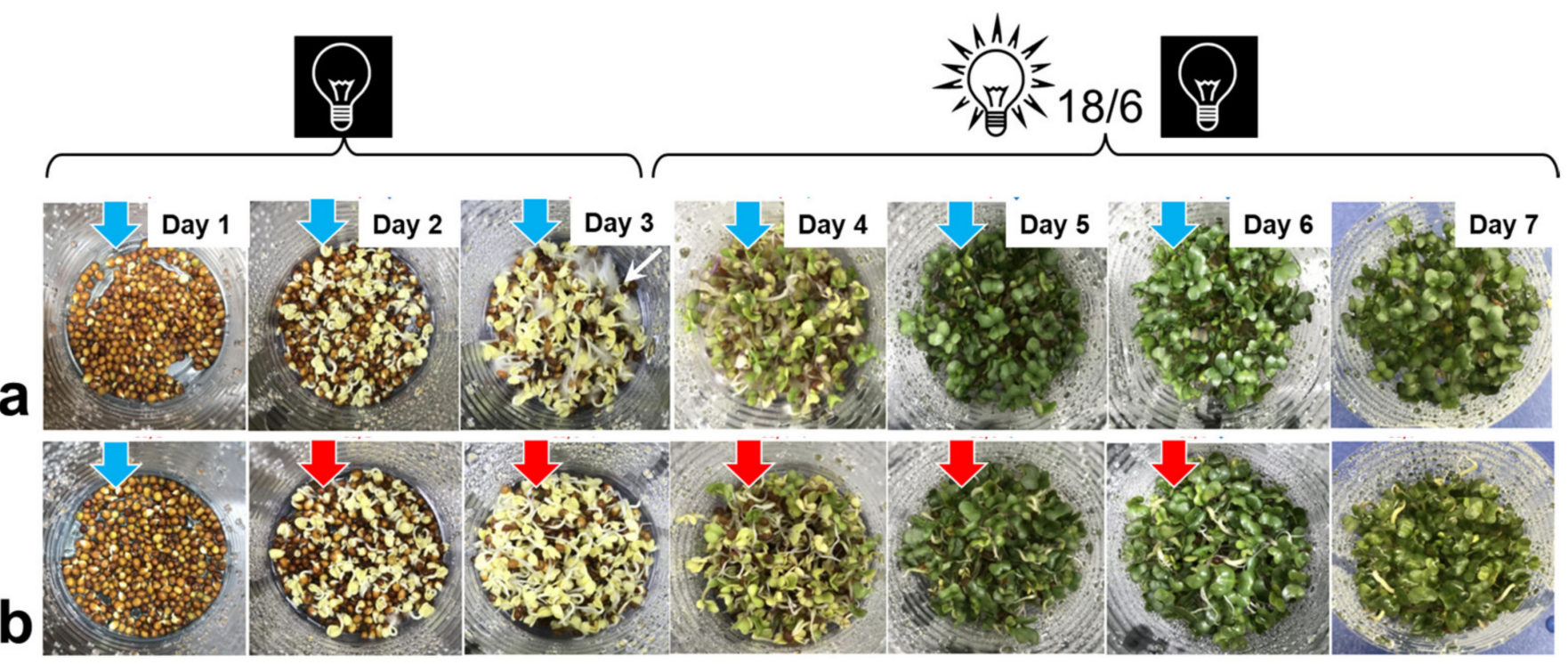

Figure 5. Appearance evolution of broccoli sprouts treated with water (control, (a)) or $1000 \mathrm{mM}$ $\mathrm{H}_{2} \mathrm{O}_{2}$ (b) during the 7-day growing cycle at $22{ }^{\circ} \mathrm{C}$. Water spraying is marked by blue arrows and $\mathrm{H}_{2} \mathrm{O}_{2}$ spraying by red arrows. Until day 3 , the sprouts were incubated in the dark and afterwards under a $18 / 6 \mathrm{~h}$ photoperiod. Note fluffy root hairs development in the control on day 3 (marked by white arrow) and negative root tropism in $\mathrm{H}_{2} \mathrm{O}_{2}$-treated sprouts starting from day 4 .

The time course of glucosinolates content on a dry weight basis is presented in Figure 6 . The sample taken for the analysis on day 1 (i.e., one day after sowing) comprised germinating and non-germinating seeds, including the seed coats, while at further sampling points (days 3, 5 and 7), only sprouts separated from seed coats and from non-germinated seeds were analyzed. In the control, the glucosinolate content on a dry weight basis stayed constant throughout the trial period and did not exceed the initial amount found in the seeds on day 1 (Figure 6). On the contrary, just one day after the first $\mathrm{H}_{2} \mathrm{O}_{2}$ spray, the glucosinolate level in the treated sprouts was significantly higher than in the control. Stimulated by repeated $\mathrm{H}_{2} \mathrm{O}_{2}$ exposures, the glucosinolate content continued to increase reaching at the end of the trial a ca. 50\% higher value than in the control. The fastest glucosinolate accumulation was evident after transferring the sprouts to light (between days 3 to 5).

The single application of $\mathrm{H}_{2} \mathrm{O}_{2}$ on day 2 resulted in certain changes of hypocotyl and root morphology, but they were not as drastic as in the case of repeated daily spraying. The sprouts that underwent a single $\mathrm{H}_{2} \mathrm{O}_{2}$ treatment showed at the end of the 7-day growth cycle $11-19 \%$ higher glucosinolate accumulation values, but this increase was not statistically significant (data not shown). On the other hand, the repeated application of $\mathrm{H}_{2} \mathrm{O}_{2}$ on etiolated sprouts continuously kept in the dark showed a significant stimulation of glucosinolate accumulation but still to a smaller extent than with light exposure by $50 \%$ and $25 \%$ on a fresh and dry weight basis, respectively (Figure 7). At the same time, the $\mathrm{H}_{2} \mathrm{O}_{2}$ treatment resulted in a significant $14 \%$ decrease in the content of phenolic compounds on 
a dry weight basis. The etiolated sprouts were longer than the light-exposed ones and yellow in color but followed a similar morphological pattern in response to $\mathrm{H}_{2} \mathrm{O}_{2}$ : relatively shorter hypocotyls and roots, enhanced root branching and negative tropism. In addition, the treated sprouts had a somewhat darker yellow color, with burning signs on cotyledon edges (Figure 7). In spite of their shorter hypocotyls, the $\mathrm{H}_{2} \mathrm{O}_{2}$-treated etiolated sprouts showed a significant 13\% increase in dry weight yield compared to the controls (Figure 7).

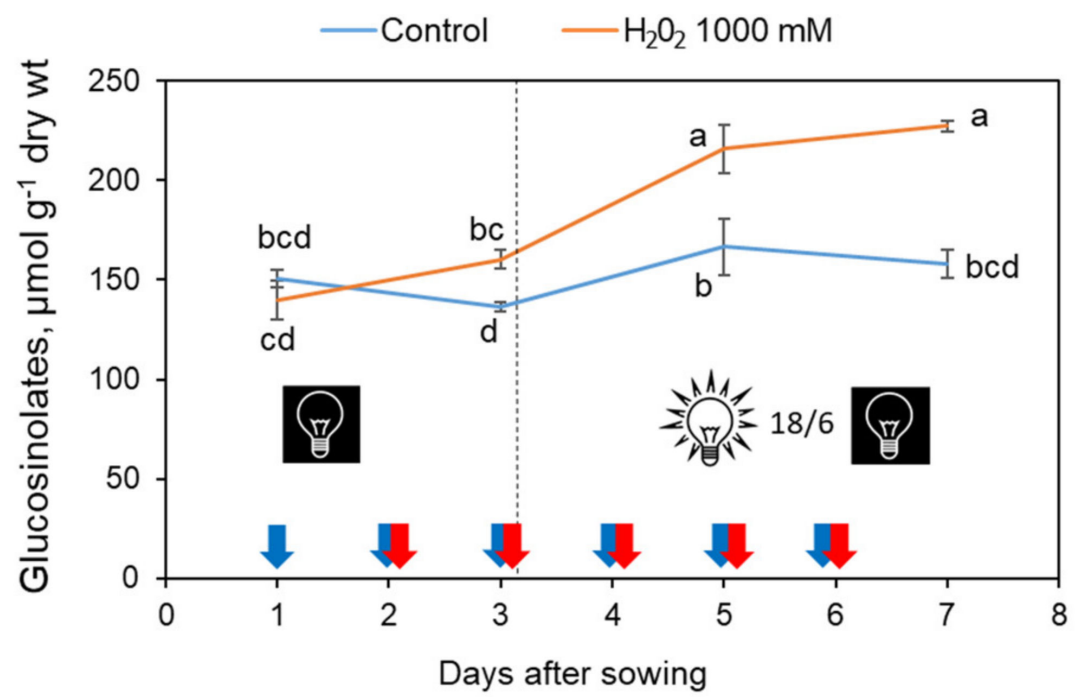

Figure 6. Time course of total glucosinolate content (on a dry weight basis) in broccoli sprouts sprayed with water (control) or $1000 \mathrm{mM} \mathrm{H}_{2} \mathrm{O}_{2}$ during the 7-day growing cycle at $22{ }^{\circ} \mathrm{C}$. Water spraying is marked by blue arrows and $\mathrm{H}_{2} \mathrm{O}_{2}$ spraying by red arrows. On day 1 , all germinating seeds were sprayed with water. Starting from day 2 until day 6 , the control sprouts were sprayed with water and the experimental sprouts with $\mathrm{H}_{2} \mathrm{O}_{2}$. Until day 3 , the sprouts were incubated in the dark and afterwards under a $18 / 6 \mathrm{~h}$ photoperiod. Different letters indicate significantly different values according to post-hoc Tukey's HSD test $(p \leq 0.05)$.
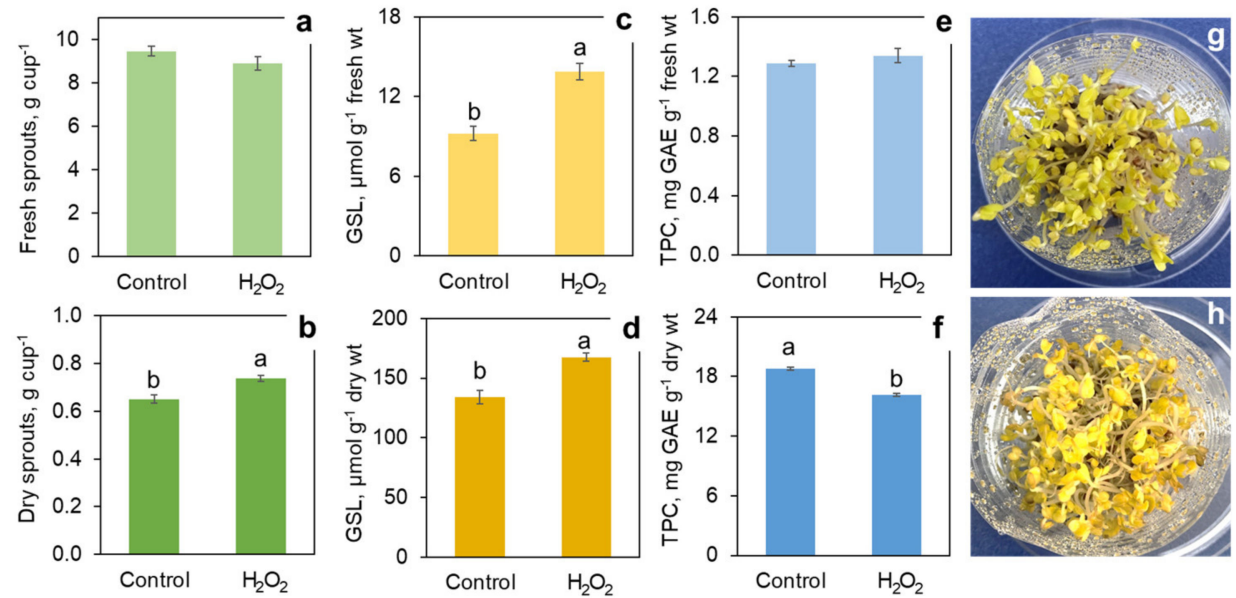

Figure 7. Effect of hydrogen peroxide treatment $\left(1000 \mathrm{mM} \mathrm{H}_{2} \mathrm{O}_{2}\right)$ in comparison with water spray (control) on yield, phytonutrients content and appearance of 7-day broccoli sprouts constantly grown in the dark at $22{ }^{\circ} \mathrm{C}$. Yield: fresh sprouts (a), dry sprouts (b); total glucosinolates (GSL) content on fresh (c) and dry (d) weight basis; total phenolic compounds (TPC) content on fresh (e) and dry (f) weight basis. Sprout appearance: control (g) and $\mathrm{H}_{2} \mathrm{O}_{2}$ treatment (h). Error bars represent standard errors of three independent biological replications. Bars marked by different letters indicate significantly different values according to post-hoc Tukey's HSD test $(p \leq 0.05)$. Absence of letters means that the values were not significantly different according to ANOVA test. 
The trial presented in Figure 8 investigated the role of cotyledons in the sprout response to $\mathrm{H}_{2} \mathrm{O}_{2}$ under regular photoperiod conditions. Cotyledons represented $25-30 \%$ of the sprout fresh weight but more than $40 \%$ of the dry weight. $\mathrm{H}_{2} \mathrm{O}_{2}$ exposure had no effect on either total fresh yield of sprouts or on the weight of fresh cotyledons per cup (Figure 8a). At the same time, the treatment resulted in a significant increase in the yield of dry sprouts and dry cotyledons weight (Figure 8b), indicating that $\mathrm{H}_{2} \mathrm{O}_{2}$ treatment made the sprouts and primarily the cotyledons denser in dry matter. In Figure $8 c$, it could be seen that $\mathrm{H}_{2} \mathrm{O}_{2}$ treatment significantly increased the content of glucosinolates by approximately $47 \mu \mathrm{mol}$ per cup, both in whole sprouts (158.7 vs. $111.7 \mu \mathrm{mol} \mathrm{cup}{ }^{-1}$ in the treated and in the control sprouts, resp.) and in the cotyledons (95.4 vs. $\left.47.8 \mu \mathrm{mol} \mathrm{cup}^{-1}\right)$. Therefore, the added glucosinolate amount was entirely contributed by cotyledons, while the treatment had no effect on the glucosinolate content in other sprout parts (hypocotyls and roots), calculated as the difference between the whole sprout and the cotyledon glucosinolate contents.
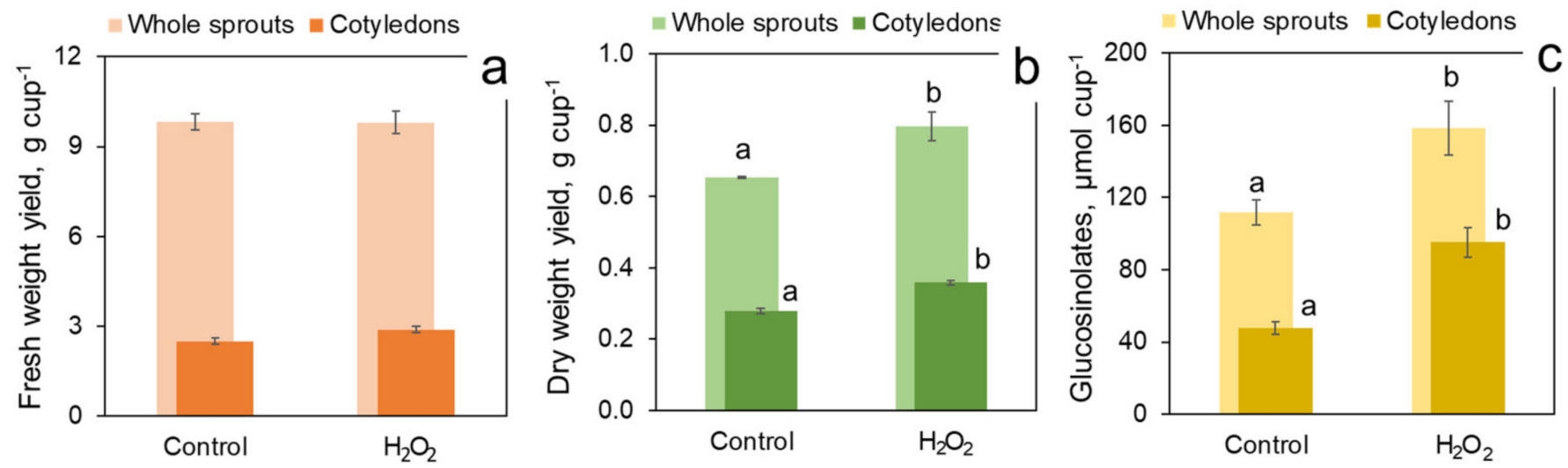

Figure 8. Contribution of cotyledons in fresh (a) and dry (b) yield and in glucosinolate content (c) of 7-day broccoli sprouts treated with $1000 \mathrm{mM} \mathrm{H}_{2} \mathrm{O}_{2}$ vs. water-sprayed control. All values are calculated per growth container. The sprouts were grown at $22{ }^{\circ} \mathrm{C}$ under illumination regime specified in Figure 5. Error bars represent standard errors of three independent biological replications. Different letters above bars indicate significant difference between the control and treatment values according to post-hoc Tukey's HSD test $(p \leq 0.05)$. Absence of letters means that the values were not significantly different according to ANOVA test.

\subsection{Effect of $1000 \mathrm{mM} \mathrm{H}_{2} \mathrm{O}_{2}$ Treatment on Wild Rocket Leaves}

In addition to the experiments performed with broccoli sprouts, a trial was performed in order to evaluate if the $\mathrm{H}_{2} \mathrm{O}_{2}$ treatment could bring a similar outcome with leafy vegetable from the same Brassicaceae family. The preharvest $1000 \mathrm{mM} \mathrm{H}_{2} \mathrm{O}_{2}$ treatment was applied in the greenhouse to wild rocket, or arugula (Diplotaxis tenuifolia), according to the same 5-day spraying protocol as with broccoli sprouts, with water spraying in the control. The treatment had a phytotoxic effect on the rocket leaves manifested as numerous bleached spots and leaves' rolling (Figure 9). Even though a marked difference on the leaves' appearance was observed, there was no significant yield difference between both groups.

The effect of $\mathrm{H}_{2} \mathrm{O}_{2}$ treatment on the phytonutrients content in rocket leaves followed a pattern similar to that with broccoli sprouts. The $\mathrm{H}_{2} \mathrm{O}_{2}$ spray tended to increase the glucosinolate contents in rocket leaves by $26 \%$ and $33 \%$ on a fresh and dry basis, respectively. However, in contrast to the sprouts, this result was not statistically significant. On the other hand, there was a significant $25 \%$ decrease in the phenolics content in fresh $\mathrm{H}_{2} \mathrm{O}_{2}$-treated leaves as compared to the controls (data not shown). 

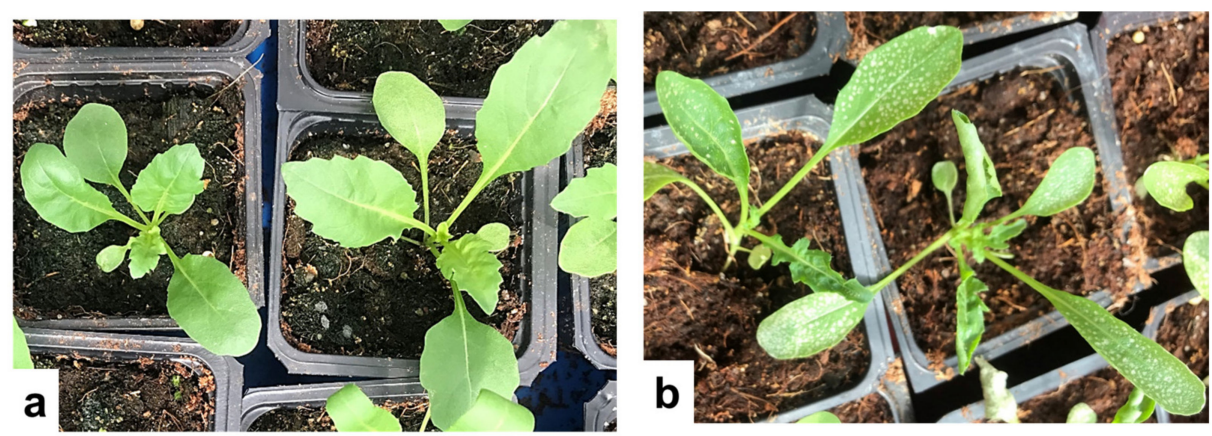

Figure 9. The appearance of 24-day greenhouse-grown wild rocket plants sprayed for 4 consecutive days starting from day 19 with $1000 \mathrm{mM} \mathrm{H}_{2} \mathrm{O}_{2}$ (b) in comparison with water-sprayed control (a).

\subsection{Effect of $\mathrm{H}_{2} \mathrm{O}_{2}$ Treatment of Broccoli Sprouts on the Expression of Genes Related to Glucosinolate Production}

Considering the significant increase in the glucosinolate content in broccoli sprouts treated with $1000 \mathrm{mM} \mathrm{H}_{2} \mathrm{O}_{2}$, a preliminary study was conducted for elucidating the molecular mechanisms of this phenomenon. The selection of genes for this study was based on their importance for the glucosinolate pathway, previous data on their expression under abiotic stress conditions and in particular the involvement of the redox status in their regulation. The genes picked for the analysis included two transcription factors influencing the biosynthesis paths of aliphatic (MYB29) and indole (MYB51) glucosinolates [19,44]. CYP (Cytochrome P450) genes were selected as genes involved in the core biosynthesis of aliphatic (CYP79F1) and indole (CYP79B3) glucosinolates. Additionally, GSH1 $(\gamma-$ glutamylcysteine synthetase) and APK1 (APS kinase) were the other two genes selected because they are involved in redox regulation for glucosinolates synthesis.

Figure 10 focuses on the expression of two competing broccoli genes involved in the mobilization of sulfur either for primary metabolism (GSH1), i.e., production of amino acid cysteine and antioxidant glutathione, or for secondary metabolism, i.e., glucosinolate biosynthesis (APK1). Figure 10a compares the expression of these genes in the $\mathrm{H}_{2} \mathrm{O}_{2}$ treated vs. the control sprouts, revealing a signigicant 3.5-fold upregulation of APK1 by $\mathrm{H}_{2} \mathrm{O}_{2}$ concomitant with glucosinolate elicitation. The expression of GSH1 was practically unaffected by $\mathrm{H}_{2} \mathrm{O}_{2}$. On the other hand, Figure $10 \mathrm{~b}$ presents the expression of the two genes on a comparable basis, relative to a housekeeping $\beta$-actin gene. According to Figure 10b, sulfur was predominantly used in the sprouts for primary metabolism, in spite of the significant stimulation of the glucosinolates formation by $\mathrm{H}_{2} \mathrm{O}_{2}$.
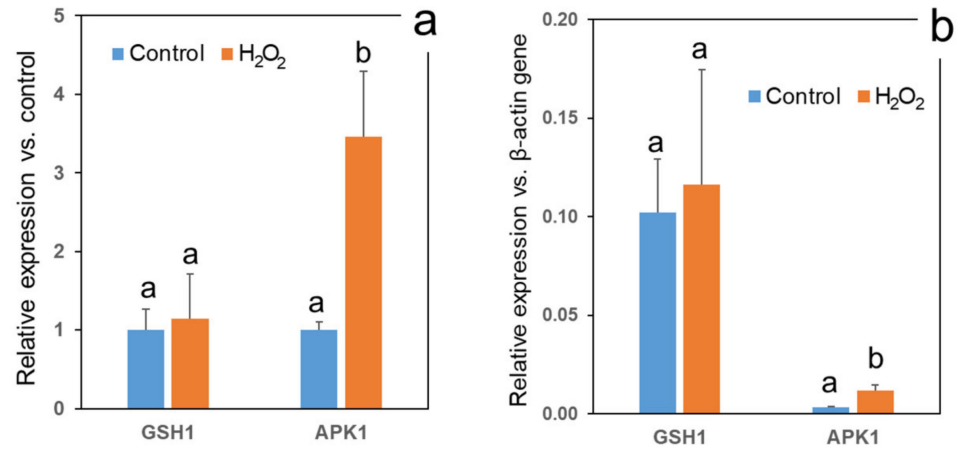

Figure 10. The effect of a single $\mathrm{H}_{2} \mathrm{O}_{2}(1000 \mathrm{mM})$ application on day 2 on relative expression of genes involved in sulfur mobilization for glucosinolate biosynthesis (APK1) and glutathione biosynthesis (GSH1) in 3-day, dark-grown broccoli sprouts as compared with water-sprayed control. The expression values normalized against the expression of the same gene in water-treated control (a) and against the expression of a housekeeping $\beta$-actin gene $(\mathbf{b})$. Error bars represent standard errors of three biological independent replications. Bars marked by different letters indicate significantly difference between $\mathrm{H}_{2} \mathrm{O}_{2}$ treatment and water control values according to $t$-test comparison $(p \leq 0.05)$. 


\section{Discussion}

\subsection{Eliciting Effect of Hydrogen Peroxide $\left(\mathrm{H}_{2} \mathrm{O}_{2}\right)$}

Undoubtedly, the high eliciting potential of hydrogen peroxide (500-1000 mM) stimulating the glucosinolate biosynthesis in broccoli sprouts is the major finding of this study. To the best of our knowledge, no previous reports on $\mathrm{H}_{2} \mathrm{O}_{2}$ as an elicitor of glucosinolate production in Brassicaceae sprouts have been published previously, and relevant information for adult plant organs is very scarce $[23,36]$. Doubling the glucosinolate content in response to $\mathrm{H}_{2} \mathrm{O}_{2}$ is one of the highest upsurges of glucosinolate content in broccoli sprouts reported. Most studies by now reached 20 to $30 \%$ addition in glucosinolate content by various elicitors, e.g., methyl jasmonate (MeJa), salicylic acid, methionine, chitosan and UV-B [45,46], and only rarely reported an increase of 80 to $98 \%[40,47,48]$. An even higher increase was achieved by combining MeJa with UV-A or UV-B [40] or by sugar feeding [49].

Plants, due to their aerobic metabolism, normally produce reactive oxygen species (ROS) such as $\mathrm{H}_{2} \mathrm{O}_{2}$ at basal levels. Hydrogen peroxide is a versatile molecule involved in plant stress signaling and the regulation of developmental processes and at the same time in direct antimicrobial protection [33,34]. However, excessive $\mathrm{H}_{2} \mathrm{O}_{2}$ concentrations can cause cell death [50,51], and therefore, its level is under the control of the antioxidative system [31]. Several authors observed the enhanced accumulation of phenolic antioxidant compounds in response to $\mathrm{H}_{2} \mathrm{O}_{2}$ in edible sprouts, in particular of the Fabaceae family. Studies on lentil sprouts revealed no differences in biomass after $\mathrm{H}_{2} \mathrm{O}_{2}$ treatments but an increase in some phenolic compounds [52]. The application of 20 to $30 \mathrm{mM} \mathrm{H}_{2} \mathrm{O}_{2}$ on lentil and chickpea sprouts showed the best results in total phenolics and antioxidant activity $[30,53]$ while in mung bean sprouts, the levels of phenolic compounds increased after the exogenous application of $400 \mathrm{mM}$ of $\mathrm{H}_{2} \mathrm{O}_{2}$ [29]. Conversely, in our studies with broccoli sprouts and rocket leaves, the phenolics content remained unchanged or slightly decreased after the application of $\mathrm{H}_{2} \mathrm{O}_{2}$. The reduced content of phenolic compounds and antioxidant activity was observed in $\mathrm{H}_{2} \mathrm{O}_{2}$-treated, fresh-cut tomatoes [54]. It cannot be excluded that the decline of phenolic antioxidant compounds observed in our trials might be due to their depletion and chemical or enzymatic degradation in the course of $\mathrm{H}_{2} \mathrm{O}_{2}$ scavenging [55-57].

\subsection{Responses of Sprout and Plant Organs to High $\mathrm{H}_{2} \mathrm{O}_{2}$ Stress}

Broccoli sprouts subjected in our study to high $\mathrm{H}_{2} \mathrm{O}_{2}$ concentrations revealed distinct phenotypical characteristics indicating their stressed state: inhibited elongation of hypocotyls and especially of roots, altered root morphology and their negative tropism and growing upwards seemingly in an attempt to escape the contact with hydrogen peroxide solution drained to the bottom of the double-cup container. It has been reported that different abiotic stresses can inhibit root elongation [58]. In particular, the application of $\mathrm{H}_{2} \mathrm{O}_{2}$ to Arabidopsis affected root growth and development due to oxidative stress [59]. At the same time, neither fresh nor dry sprout yield declined in our trials. Presumably, shortening of the sprouts was compensated by the increase in their thickness, density and/or number per cup.

It should be noted that in our trials, similar to the typical industrial practice [37], the seeds were germinated on water so that their stored nutrients (and later, also photosynthesis products) were the only energy and material sources for sprout growth and metabolism. Such a situation may create competition between the secondary metabolism enhanced by elicitation and normal sprout development, resulting in sprout distortion, even though no yield decline was registered in the $\mathrm{H}_{2} \mathrm{O}_{2}$-treated sprouts. We have found recently that combined $\mathrm{H}_{2} \mathrm{O}_{2}$ and oligosaccharide application partially alleviated the $\mathrm{H}_{2} \mathrm{O}_{2}$-caused morphological anomalities of sprouts and significantly stimulated their yield and phenolic and glucosinolate contents [60]. On the other hand, without $\mathrm{H}_{2} \mathrm{O}_{2}$ elicitation, fertilization of broccoli sprouts with inorganic [61] or organic (amino acid) [62] sulfur and nitrogen sources had only insignificant effect on glucosinolate production. 
Cotyledons were revealed in our study as the site of enhanced glucosinolate accumulation in response to $\mathrm{H}_{2} \mathrm{O}_{2}$ treatment. In the same way, Pérez-Balibrea et al. [63] described the broccoli cotyledons as the organ with the highest bioactive compounds accumulation (vitamin C, glucosinolates and phenolics). The cotyledons showed no bleaching in response to $\mathrm{H}_{2} \mathrm{O}_{2}$ application on their surface, in contrast to real leaves of the rocket plant subjected to the same treatment. The better ability of sprouts, as compared to adult plant organs, to mitigate the $\mathrm{H}_{2} \mathrm{O}_{2}$ phytotoxicity might be related to their stronger enzymatic and non-enzymatic antioxidant protection [64]. Similarly, the Arabidopsis seedlings had higher antioxidant capacity than mature leaves, defending them from energy imbalance in the mitochondria [65]. Notably, the same $\mathrm{H}_{2} \mathrm{O}_{2}$ treatment caused stronger glucosinolate stimulation in sprouts than in the rocket leaves. The richness of broccoli sprouts in glucosinolates far exceeding their content in mature plant organs is well known [15].

In the trials with greenhouse-grown wild rocket, a leaf toxicity of $1000 \mathrm{mM} \mathrm{H}_{2} \mathrm{O}_{2}$ was evident as scattered bleaching of the leaves within $24 \mathrm{~h}$ after application. This result was similar to the findings of Eicher-Sodo et al. [66], who observed damage on arugula leaves after daily foliar $\mathrm{H}_{2} \mathrm{O}_{2}$ treatment for 11 days using milder $\mathrm{H}_{2} \mathrm{O}_{2}$ concentrations compared with our study. $\mathrm{H}_{2} \mathrm{O}_{2}$ leads to programmed cell death as a defense mechanism of the plants [67]. On the other hand, optimizing the treatment conditions might alleviate its negative effects and maximize the positive ones. For example, foliar treatment of the greenhouse-grown mustard plants with $200 \mathrm{mM} \mathrm{H}_{2} \mathrm{O}_{2}$ resulted in greater glucosinolate stimulation than the higher dose of $400 \mathrm{mM}$ [36]. While the modest $17 \%$ increase in glucosinolate content in mustard leaves was similar to our results with the leaves of wild rocket, the flowers and seeds of $\mathrm{H}_{2} \mathrm{O}_{2}$-treated mustard plant showed much more significant increases of $96 \%$ and $78 \%$, respectively. On the contrary, the $\mathrm{H}_{2} \mathrm{O}_{2}$ treatment significantly reduced the glucosinolate content in mustard roots [36]. The relationship between peculiarities of enzymatic and non-enzymatic antioxidant systems in different plant species and organs and their response to ROS elicitors such as $\mathrm{H}_{2} \mathrm{O}_{2}$ deserves further investigation.

\subsection{Effect of $\mathrm{H}_{2} \mathrm{O}_{2}$ Treatment on Genes Expression}

Considering the $\mathrm{H}_{2} \mathrm{O}_{2}$-induced upsurge in the total glucosinolates level, we hypothesized that this phenomenon could be associated with the upregulation of the relevant genes' expression. The preliminary study included two transcription factor genes regulating the pathways of aliphatic (MYB29) and indole (MYB51) glucosinolates, a gene responsible for involving tryptophan in the indole glucosinolates biosynthesis (CYP79B3), and two redox-regulated genes dealing with sulfur mobilization into competing pathways to glucosinolates (APK1) or to the antioxidant glutathione (GSH1). Although the $\mathrm{H}_{2} \mathrm{O}_{2}$-treated sprouts showed a somewhat higher expression of all genes listed, a statistically significant relative expression difference between the treatment and the control was found only for APK1. This upregulation was coherent with the activation of the glucosinolate synthesis by $\mathrm{H}_{2} \mathrm{O}_{2}$ because APK1 and APK2 are important for glucosinolates formation [68]. The lack of significance of the other genes tested does not necessarily mean that they were not affected by $\mathrm{H}_{2} \mathrm{O}_{2}$. The detection of such effects might need a more detailed time course study of gene expression.

APK is involved in providing sulfur for glucosinolates formation in a form of adenosine $5^{\prime}$-phosphosulfate (APS). The APS can undergo two alternative metabolic directions: either reduction by APS reductase to form cysteine and further gluthathione by GSH1 [65], or phosphorylation by APS kinase (APK, in particular APK1) to form 3'-phosphoadenosine $5^{\prime}$-phosphosulfate (PAPS), which donates the sulfur group to glucosinolates formation [69]. Thus, sulfur groups can be partitioned into the primary metabolism, e.g., cysteine and glutathione, and secondary metabolism, e.g., glucosinolates [70]. It is accepted that the balance between APS reductase and APS kinase is redox-regulated. APS reductase is upregulated at an oxidative state, neutralizing the oxidative stress by enhanced glutathione activity, while APS kinase activity prevails at a reduced state [26]. Nevertheless, our results apparently contradict this scheme because a significant upregulation of APK1 was caused 
by an oxidizing factor, $\mathrm{H}_{2} \mathrm{O}_{2}$. This phenomenon may be associated with a constitutive high antioxidant status of broccoli sprouts rich in enzymatic and non-enzymatic antioxidants [71,72]. Indeed, when presented in comparable form, relative to the expression of a housekeeping gene $\beta$-actin, the expression of GSH1 gene in our analyses was much higher than that of APK1, irrespective of $\mathrm{H}_{2} \mathrm{O}_{2}$ treatment. Further study is needed to check if the redox homeostasis of broccoli sprouts after $\mathrm{H}_{2} \mathrm{O}_{2}$ treatment can justify the APK1 upregulation leading to enhanced glucosinolates formation.

\section{Conclusions}

The research has shown that $\mathrm{H}_{2} \mathrm{O}_{2}$ in high concentrations $(500-1000 \mathrm{mM})$ is a prominent elicitor for the enrichment of broccoli sprouts with glucosinolates without a negative effect on their yield. However, an attempt to extend this approach to wild rocket plants in the greenhouse resulted in phytotoxic damage to the leaves and limited glucosinolates enhancement. The study has made the initial steps towards understanding the mechanisms of the $\mathrm{H}_{2} \mathrm{O}_{2}$ effect by investigating the relevant genes expression. The first encouraging finding was the effects of $\mathrm{H}_{2} \mathrm{O}_{2}$ on upregulating the glucosinolate-associated gene APK1. Further methodological improvements are needed in order to decipher the elicitation fenomenon and to develop a capability to manipulate it in desirable direction.

Author Contributions: Conceptualization, V.R.; methodology, V.R., A.V.T. and N.T.; validation, A.V.T. and N.T.; formal analysis, A.V.T.; investigation, A.V.T. and N.T.; resources, V.R.; data curation, A.V.T.; writing — original draft preparation, A.V.T.; writing—review and editing, V.R.; visualization, A.V.T. and V.R.; supervision, V.R.; project administration, V.R.; funding acquisition, V.R. All authors have read and agreed to the submitted version of the manuscript. All authors have read and agreed to the published version of the manuscript.

Funding: This research was funded by the Nitzan program of the Chief Scientist's Office of the Israeli Ministry of Agriculture and Rural Development, grant number 20-06-0094.

Institutional Review Board Statement: Not applicable.

Informed Consent Statement: Not applicable.

Data Availability Statement: The data presented in this study are available on request from the corresponding author.

Acknowledgments: The authors are grateful to David Kenigsbuch (ARO) for the provision of seeds, equipment, the greenhouse facility and instructions on growing the wild rocket plants. We are grateful to Amnon Lers (ARO) and his team, in particular Maria Dolores Camalle, for the support with the RT-qPCR assay.

Conflicts of Interest: The authors declare no conflict of interest. The funders had no role in the design of the study; in the collection, analyses, or interpretation of data; in the writing of the manuscript, or in the decision to publish the results.

\section{References}

1. Jahangir, M.; Kim, H.K.; Choi, Y.H.; Verpoorte, R. Health-affecting compounds in Brassicaceae. Compr. Rev. Food Sci. Food Saf. 2009, 8, 31-43. [CrossRef]

2. Avato, P.; Argentieri, M.P. Brassicaceae: A rich source of health improving phytochemicals. Phytochem. Rev. 2015, 14, 1019-1033. [CrossRef]

3. Raiola, A.; Errico, A.; Petruk, G.; Monti, D.M.; Barone, A.; Rigano, M.M. Bioactive compounds in brassicaceae vegetables with a role in the prevention of chronic diseases. Molecules 2018, 23, 15. [CrossRef] [PubMed]

4. Sahai, V.; Kumar, V. Anti-diabetic, hepatoprotective and antioxidant potential of Brassica oleracea sprouts. Biocatal. Agric. Biotechnol. 2020, 25, 101623. [CrossRef]

5. Cartea, M.E.; Francisco, M.; Soengas, P.; Velasco, P. Phenolic compounds in Brassica vegetables. Molecules 2011, 16, 251-280. [CrossRef]

6. Dinkova-Kostova, A.T.; Kostov, R.V. Glucosinolates and isothiocyanates in health and disease. Trends Mol. Med. 2012, 18, 337-347. [CrossRef]

7. Moreno, D.A.; Carvajal, M.; López-Berenguer, C.; García-Viguera, C. Chemical and biological characterisation of nutraceutical compounds of broccoli. J. Pharm. Biomed. Anal. 2006, 41, 1508-1522. [CrossRef] 
8. Rosa, E.A. Chemical composition. In Biology of Brassica Coenospecies, 1st ed.; Gomez-Campo, C., Ed.; Developments in Plant Genetics and Breeding; Elsevier Science B.V.: Amsterdam, The Netherlands, 1999; Volume 4, pp. 315-357.

9. Grubb, C.D.; Abel, S. Functional detection of chemopreventive glucosinolates in Arabidopsis thaliana. Plant Sci. J. 2000, 159, 265-272. [CrossRef]

10. Yan, X.; Chen, S. Regulation of plant glucosinolate metabolism. Planta 2007, 226, 1343-1352. [CrossRef]

11. Śmiechowska, A.; Bartoszek, A.; Namieśnik, J. Determination of glucosinolates and their decomposition products-Indoles and isothiocyanates in cruciferous vegetables. Crit. Rev. Anal. Chem. 2010, 40, 202-216. [CrossRef]

12. Björkman, M.; Klingen, I.; Birch, A.N.E.; Bones, A.M.; Bruce, T.J.A.; Johansen, T.J.; Meadow, R.; Mølmann, J.; Seljåsen, R.; Smart, L.E.; et al. Phytochemicals of Brassicaceae in plant protection and human health-Influences of climate, environment and agronomic practice. Phytochemistry 2011, 72, 538-556. [CrossRef]

13. Barba, F.J.; Nikmaram, N.; Roohinejad, S.; Khelfa, A.; Zhu, Z.; Koubaa, M. Bioavailability of glucosinolates and their breakdown products: Impact of processing. Front. Nutr. 2016, 3, 24. [CrossRef]

14. Zhang, Y.; Kensler, T.W.; Cho, C.G.; Posner, G.H.; Talalay, P. Anticarcinogenic activities of sulforaphane and structurally related synthetic norbornyl isothiocyanates. Proc. Natl. Acad. Sci. USA 1994, 91, 3147-3150. [CrossRef]

15. Fahey, J.; Zhang, Y.; Talalay, P. Broccoli sprouts: An exceptionally rich source of inducers of enzymes that protect against chemical carcinogens. Proc. Natl. Acad. Sci. USA 1997, 94, 10367-10372. [CrossRef]

16. Le, N.T.; Luong, H.Q.; Li, H.P.; Chiu, C.H.; Hsieh, P.C. Broccoli (Brassica oleracea L. var. Italica) sprouts as the potential food source for bioactive properties: A comprehensive study on in vitro disease models. Foods 2019, 8, 532. [CrossRef]

17. Gan, R.Y.; Lui, W.Y.; Wu, K.; Chan, C.L.; Dai, S.H.; Sui, Z.Q.; Corke, H. Bioactive compounds and bioactivities of germinated edible seeds and sprouts: An updated review. Trends Food Sci. Technol. 2017, 59, 1-14. [CrossRef]

18. Galieni, A.; Falcinelli, B.; Stagnari, F.; Datti, A.; Benincasa, P. Sprouts and microgreens: Trends, opportunities, and horizons for novel research. Agronomy 2020, 10, 1424. [CrossRef]

19. Gao, J.; Yu, X.; Ma, F.; Li, J. RNA-seq analysis of transcriptome and glucosinolate metabolism in seeds and sprouts of broccoli (Brassica oleracea var. italica). PLoS ONE 2014, 9, e88804. [CrossRef]

20. Chhajed, S.; Mostafa, I.; He, Y.; Abou-hashem, M.; El-domiaty, M. Glucosinolate biosynthesis and the glucosinolate-myrosinase system in plant defense. Agronomy 2020, 10, 1786. [CrossRef]

21. Yu, Q.; Hao, G.; Zhou, J.; Wang, J.; Evivie, E.R.; Li, J. Identification and expression pattern analysis of BoMYB51 involved in indolic glucosinolate biosynthesis from broccoli (Brassica oleracea var. italica). Biochem. Biophys. Res. Commun. 2018, 501, 598-604. [CrossRef]

22. Zuluaga, D.L.; Graham, N.S.; Klinder, A.; van Ommen Kloeke, A.E.; Marcotrigiano, A.R.; Wagstaff, C.; Verkerk, R.; Sonnante, G.; Aarts, M.G. Overexpression of the MYB29 transcription factor affects aliphatic glucosinolate synthesis in Brassica oleracea. Plant Mol. Biol. 2019, 101, 65-79. [CrossRef]

23. Duarte-Sierra, A.; Hasan, M.; Michaud, D.; Arul, J.; Forney, C.F. Effect of oxidase stresses on glucosinolates profile in broccoli florets during postharvest storage. Acta Hortic. 2013, 1012, 361-367.

24. Guo, L.; Yang, R.; Zhou, Y.; Gu, Z. Heat and hypoxia stresses enhance the accumulation of aliphatic glucosinolates and sulforaphane in broccoli sprouts. Eur. Food Res. Technol. 2016, 242, 107-116. [CrossRef]

25. Sønderby, I.E.; Geu-Flores, F.; Halkier, B.A. Biosynthesis of glucosinolates-gene discovery and beyond. Trends Plant Sci. 2010, 15, 283-290. [CrossRef]

26. Kopriva, S.; Gigolashvili, T. Glucosinolate synthesis in the context of plant metabolism. Adv. Bot. Res. 2016, 80, 99-124. [CrossRef]

27. Mishra, A.K.; Sharma, K.; Misra, R.S. Elicitor recognition, signal transduction and induced resistance in plants. J. Plant Interact. 2012, 7, 95-120. [CrossRef]

28. Baenas, N.; García-Viguera, C.; Moreno, D.A. Elicitation: A tool for enriching the bioactive composition of foods. Molecules 2014, 19, 13541-13563. [CrossRef] [PubMed]

29. Cevallos Casals, B.A. Synthesis of Antioxidant Phenolic Compounds in Seed Sprout Models in Response to Plant Elicitors and Stressors. Ph.D. Thesis, Texas A\&M University, College Station, TX, USA, 2006.

30. Świeca, M. Elicitation with abiotic stresses improves pro-health constituents, antioxidant potential and nutritional quality of lentil sprouts. Saudi J. Biol. Sci. 2015, 22, 409-416. [CrossRef] [PubMed]

31. Smirnoff, N.; Arnaud, D. Hydrogen peroxide metabolism and functions in plants. New Phytol. 2019, 221, 1197-1214. [CrossRef]

32. Desikan, R.; Cheung, M.K.; Bright, J.; Henson, D.; Hancock, J.T.; Neill, S.J. ABA, hydrogen peroxide and nitric oxide signalling in stomatal guard cells. J. Exp. Bot. 2004, 55, 205-212. [CrossRef]

33. Wojtyla, Ł.; Lechowska, K.; Kubala, S.; Garnczarska, M. Different modes of hydrogen peroxide action during seed germination. Front. Plant Sci. 2016, 7, 66. [CrossRef]

34. Quan, L.J.; Zhang, B.; Shi, W.W.; Li, H.Y. Hydrogen peroxide in plants: A versatile molecule of the reactive oxygen species network. J. Integr. Plant Biol. 2008, 50, 2-18. [CrossRef] [PubMed]

35. Hossain, M.A.; Bhattacharjee, S.; Armin, S.M.; Qian, P.; Xin, W.; Li, H.Y.; Burritt, D.J.; Fujita, M.; Tran, L.S.P. Hydrogen peroxide priming modulates abiotic oxidative stress tolerance: Insights from ROS detoxification and scavenging. Front. Plant Sci. 2015, 6, 420. [CrossRef] [PubMed] 
36. Arriaga-Madrid, D.A.; Guevara González, R.; Feregrino Pérez, A.; ContrerasMedina, L.M.; Cortez Pérez, A. Production of glucosinolates in different organs of white mustard plant (Sinapsis alba L.) as a result of the application of hydrogen peroxide. In Proceedings of the 13th International Engineering Congress, Santiago de Queretaro, Mexico, 15-19 May 2017; IEEE: New York, NY, USA, 2017. [CrossRef]

37. National Advisory Committee on Microbiological Criteria for Foods (NACMCF). Microbiological safety evaluations and recommendations on sprouted seeds. Int. J. Food Microbiol. 1999, 52, 123-153. [CrossRef]

38. Noble, R.W.; Gibson, Q.H. The reaction of ferrous horseradish peroxidase with hydrogen peroxide. J. Biol. Chem. 1970, 245, 2409-2413. [CrossRef]

39. Villarreal-García, D.; Nair, V.; Cisneros-Zevallos, L.; Jacobo-Velázquez, D.A. Plants as biofactories: Postharvest stress-induced accumulation of phenolic compounds and glucosinolates in broccoli subjected to wounding stress and exogenous phytohormones. Front. Plant Sci. 2016, 7, 45. [CrossRef]

40. Moreira-Rodríguez, M.; Nair, V.; Benavides, J.; Cisneros-Zevallos, L.; Jacobo-Velázquez, D.A. UVA, UVB light doses and harvesting time differentially tailor glucosinolate and phenolic profiles in broccoli sprouts. Molecules 2017, 22, 1065. [CrossRef]

41. Ishida, M.; Nagata, M.; Ohara, T.; Kakizaki, T.; Hatakeyama, K.; Nishio, T. Small variation of glucosinolate composition in Japanese cultivars of radish (Raphanus sativus L.) requires simple quantitative analysis for breeding of glucosinolate component Breed. Sci. 2012, 62, 63-70. [CrossRef]

42. Singleton, V.L.; Rossi, J.A., Jr. Colorimetry of total phenolics with phosphomolybdic-phosphotungstic acid reagents. Am. J. Enol. Vitic. 1965, 16, 144-158.

43. Slinkard, K.; Singleton, V. Total phenol analysis: Automation and comparison with manual methods. Am. J. Enol. Vitic. 1977, 28, 49-55. [CrossRef]

44. Araki, R.; Hasumi, A.; Nishizawa, O.I.; Sasaki, K.; Kuwahara, A.; Sawada, Y.; Totoki, Y.; Toyoda, A.; Sakaki, Y.; Li, Y.; et al. Novel bioresources for studies of Brassica oleracea: Identification of a kale MYB transcription factor responsible for glucosinolate production. Plant Biotechnol. J. 2013, 11, 1017-1027. [CrossRef]

45. Martínez-Zamora, L.; Castillejo, N.; Artés-Hernández, F. Postharvest UV-B and UV-C radiation enhanced the biosynthesis of glucosinolates and isothiocyanates in Brassicaceae sprouts. Postharvest Biol. Technol. 2021, 181, 111650. [CrossRef]

46. Pérez-Balibrea, S.; Moreno, D.A.; García-Viguera, C. Improving the phytochemical composition of broccoli sprouts by elicitation. Food Chem. 2011, 129, 35-44. [CrossRef]

47. Baenas, N.; García-Viguera, C.; Moreno, D.A. Biotic elicitors effectively increase the glucosinolates content in Brassicaceae sprouts J. Agric. Food Chem. 2014, 62, 1881-1889. [CrossRef]

48. Castillejo, N.; Martínez-Zamora, L.; Gómez, P.A.; Pennisi, G.; Crepaldi, A.; Fernández, J.A.; Orsini, F.; Artés-Hernández, F. Postharvest yellow LED lighting affects phenolics and glucosinolates biosynthesis in broccoli sprouts. J. Food Compos. Anal. 2021, 103, 104101. [CrossRef]

49. Guo, R.; Yuan, G.; Wang, Q. Sucrose enhances the accumulation of anthocyanins and glucosinolates in broccoli sprouts. Food Chem. 2011, 129, 1080-1087. [CrossRef]

50. Gechev, T.S.; Hille, J. Hydrogen peroxide as a signal controlling plant programmed cell death. J. Cell Biol. 2005, 168, 17-20. [CrossRef]

51. Gupta, K.; Sengupta, A.; Chakraborty, M.; Gupta, B. Hydrogen peroxide and polyamines act as double edged swords in plant abiotic stress responses. Front. Plant Sci. 2016, 7, 1343. [CrossRef]

52. Świeca, M.; Baraniak, B. Influence of elicitation with $\mathrm{H}_{2} \mathrm{O}_{2}$ on phenolics content, antioxidant potential and nutritional quality of Lens culinaris sprouts. J. Sci. Food Agric. 2014, 94, 489-496. [CrossRef]

53. León-López, L.; Escobar-Zúñiga, Y.; Salazar-Salas, N.Y.; Mora Rochín, S.; Cuevas-Rodríguez, E.O.; Reyes-Moreno, C.; MilánCarrillo, J. Improving polyphenolic compounds: Antioxidant activity in chickpea sprouts through elicitation with hydrogen peroxide. Foods 2020, 9, 1791. [CrossRef]

54. Kim, H.J.; Fonseca, J.M.; Kubota, C.; Choi, J.H. Effect of hydrogen peroxide on quality of fresh-cut tomato. J. Food Sci. 2007, 72, S463-S467. [CrossRef] [PubMed]

55. Takahama, U. Oxidation of flavonols by hydrogen peroxide in epidermal and guard cells of Vicia faba L. Plant Cell Physiol. 1988, 29, 433-438. [CrossRef]

56. Kikugawa, K.; Kunugi, A.; Kurechi, T. Chemistry and implications of degradation of phenolic antioxidants. In Food Antioxidants, Hudson, B.J.F., Ed.; Elsevier Applied Science: London, UK; New York, NY, USA, 1990; pp. 65-98. [CrossRef]

57. Calderon, A.I.; Wright, B.J.; Hurst, W.J.; Van Breemen, R.B. Screening antioxidants using LC-MS: Case study with cocoa. J. Agric. Food Chem. 2009, 57, 5693-5699. [CrossRef] [PubMed]

58. Potters, G.; Pasternak, T.P.; Guisez, Y.; Palme, K.J.; Jansen, M.A.K. Stress-induced morphogenic responses: Growing out of trouble? Trends Plant Sci. 2007, 12, 98-105. [CrossRef]

59. Zhou, L.; Hou, H.; Yang, T.; Lian, Y.; Sun, Y.; Bian, Z.; Wang, C. Exogenous hydrogen peroxide inhibits primary root gravitropism by regulating auxin distribution during Arabidopsis seed germination. Plant Physiol. Biochem. 2018, 128, 126-133. [CrossRef]

60. Shebis, Y.; Vanegas, A.; Tish, N.; Fallik, E.; Rodov, V.; Poverenov, E. Facile method for preparation of oligo-carboxymethyl cellulose and other oligosaccharides: Physicochemical properties and bioactivity. Food Hydrocoll. 2022, 127, 107530. [CrossRef]

61. Aires, A.; Rosa, E.; Carvalho, R. Effect of nitrogen and sulfur fertilization on glucosinolates in the leaves and roots of broccoli sprouts (Brassica oleracea var. italica). J. Sci. Food Agric. 2006, 86, 1512-1516. [CrossRef] 
62. Vanegas Torres, A. Enhancing the Content of Phytonutrients in Broccoli Sprouts by Application of Elicitors. Master's Thesis, The Hebrew University of Jerusalem, Rehovot, Israel, 2021.

63. Pérez-Balibrea, S.; Moreno, D.A.; García-Viguera, C. Influence of light on health-promoting phytochemicals of broccoli sprouts. J. Sci. Food Agric. 2008, 88, 904-910. [CrossRef]

64. Shetty, K. Role of proline-linked pentose phosphate pathway in biosynthesis of plant phenolics for functional food and environmental applications: A review. Process Biochem. 2004, 39, 789-803. [CrossRef]

65. Réthoré, E.; d'Andrea, S.; Benamar, A.; Cukier, C.; Tolleter, D.; Limami, A.M. Arabidopsis seedlings display a remarkable resilience under severe mineral starvation using their metabolic plasticity to remain self-sufficient for weeks. Plant J. 2019, 99, 302-315. [CrossRef]

66. Eicher-Sodo, M.; Gordon, R.; Zheng, Y. Characterizing the phytotoxic effects of hydrogen peroxide on common microgreen species and lettuce cultivars. HortTechnology 2019, 29, 283-289. [CrossRef]

67. Houot, V.; Etienne, P.; Petitot, A.S.; Barbier, S.; Blein, J.P.; Suty, L. Hydrogen peroxide induces programmed cell death features in cultured tobacco BY-2 cells, in a dose-dependent manner. J. Exp. Bot. 2001, 52, 1721-1730. [CrossRef]

68. Mugford, S.G.; Yoshimoto, N.; Reichelt, M.; Wirtz, M.; Hill, L.; Mugford, S.T.; Nakazato, Y.; Noji, M.; Takahashi, H.; Kramell, R.; et al. Disruption of adenosine-5' -phosphosulfate kinase in Arabidopsis reduces levels of sulfated secondary metabolites. Plant Cell 2009, 21, 910-927. [CrossRef]

69. Kopriva, S. Regulation of sulfate assimilation in Arabidopsis and beyond. Ann. Bot. 2006, 97, 479-495. [CrossRef]

70. Kopriva, S.; Mugford, S.G.; Baraniecka, P.; Lee, B.R.; Matthewman, C.A.; Koprivova, A. Control of sulfur partitioning between primary and secondary metabolism in Arabidopsis. Front. Plant Sci. 2012, 3, 163. [CrossRef]

71. López-Cervantes, J.; Tirado-Noriega, L.G.; Sánchez-Machado, D.I.; Campas-Baypoli, O.N.; Cantú-Soto, E.U.; Núñez-Gastélum, J.A. Biochemical composition of broccoli seeds and sprouts at different stages of seedling development. Int. J. Food Sci. Technol. 2013, 48, 2267-2275. [CrossRef]

72. Ahmad, P.; Jaleel, C.A.; Salem, M.A.; Nabi, G.; Sharma, S. Roles of enzymatic and nonenzymatic antioxidants in plants during abiotic stress. Crit. Rev. Biotechnol. 2010, 30, 161-175. [CrossRef] 